\title{
MUSLIMS WITH TATTOOS The Punk Muslim Community in Indonesia
}

\author{
Mohammad Rokib*; Syamsul Sodiq** \\ *, ** Universitas Negeri Surabaya, Indonesia \\ email:mohammadrokib@unesa.ac.id
}

\begin{abstract}
Tattooing is becoming increasingly popular in the predominantly Muslim country of Indonesia. While mainstream society continues to perceive the tattooing practice negatively, many individual Muslims attach positive personal meaning to tattooing. This paper provides some of the academic insights into contemporary perceptions of tattooing among Indonesian Muslims. It focuses on the existence of 'Punk Muslims' community whose tattoos form an important part of their cultural identity and on responses to their tattooing practices from the wider society. Data were collected by means of individual interviews, a focus group discussion, and interactive social media communication. This paper reveals that Punk Muslim community has personal meaning of tattoo, while society has different perception. This community considers to maintain their cultural identity as punker symbolized by tattoo and Islam signed by worship. Tato menjadi semakin populer di negara mayoritas Muslim seperti Indonesia. Ketika sebagian besar masyarakat memandang tato secara negatif, banyak juga Muslim secara pribadi memiliki pendapatpositif terhadap tato. Artikel ini menyugubkan beberapa wawasan akademik atas persepsi kontemporer terhadap tato dalam masyarakat Muslim di Indonesia. Fokus dari artikel ini meliputi eksistensi komunitas Punk Muslim yang menganggap tato telah membentuk bagian sangat penting dari identitas kultural mereka dan juga fokus pada respons dari masyarakat terhadap praktik bertato. Data penelitian dikumpulkan dari interview secara personal, diskusi
\end{abstract}


kelompok terumpun, dan komunikasi interaktif di media sosial. Artikel ini menyatakan bahwa komunitas Punk. Muslim memiliki makna personal atas tato ketika masyarakat memiliki penilaian yang berbeda. Komunitas ini mempertimbangkan untuk mempertabamkan identitas kultural sebagai anak punk yang disimbolkan dengan tato dan sebagai orang Islam yang disimbolkan dengan ibadah.]

Keywords: tattoos, punk muslim, Islam in Indonesia.

\section{A. Introduction}

Discussing tattoo relates to Islamic tenets and its practices indicate an old but unique topic, particularly in the expression of Muslims with tattoos. Even though Islam and tattooing become an old question regard to Muslim theologian agreement that tattooing is haram (forbidden), Muslim practices today challenge a new perspective to understand the relationship between argument of haram on tattoo and the practice of tattooing for some Muslims. In the Islamic sect of Sunni which has a large number of followers in Indonesia, all of the kinds of tattoo are considered forbidden and a sin, while in Islamic sect of Shia those kinds of tattoo are still debatable. Practically the use of temporary tattoos-especially made with henna-is very common and is considered permissible in Muslim Morocco and predominantly Muslim nations such as Indonesia as the phenomenon of popular Islam in the globalized world. ${ }^{1}$

As the world's largest Sunni based Muslim population, Indonesia

${ }^{1}$ Most of Muslim nations in the Middle East and North Africa shape similar issue of popular youth culture. See Walid El Hamamsy and Mounira Soliman (eds.), Popular Culture in the Middle East and North Africa: A Postcolonial Outlook (New York: Routledge, 2013). Kamaludeen Mohamed Nasir explored on how young Muslims in Singapore and Sydney attempt to gain entry into mainstream youth culture relate to tattooing issue and common traditional views in the society. Kamaludeen Mohamed Nasir, "Tattooing the Muslim Youth Body", in Globalized Muslim youth in the Asia Pacific: Popular Culture in Singapore and Sydney (Hampshire: Palgrave Macmillan, 2016), pp. 115-49. In the similar sense of popular culture, Farish A Noor identified that popular Islam is expressed everywhere in today's Muslim world through different forms. See Farish A. Noor, "Popular Religiosity in Indonesia Today: The Next Step after 'Islam Kultural'?", Al-Jami'ab: Journal of Islamic Studies, vol. 53, no. 2 (2015), pp. 283-302.Another case of Muslim nation is Malaysia. See Dominik Michael Müller, Islam, Politics and Youth in Malaysia: The Pop-Islamist Reinvention of PAS (Abingdon [u.a.: Routledge, 2014). 
has hundreds of tattoo studios, clinics and shops either circulated via online and offline. ${ }^{2}$ A community of tattoo with henna called Henna Club Indonesia, for example, has more than 200 studios of business networks throughout Indonesia as presented in its website of www. hennaclubindonesia.blogspot.com. Other community such as Java Tattoo Club Indonesia at www.oocities.org/tattoosind has fifteen studios of business networks and more around Java Island. Most of tattoo customers of those studios are Muslim young generation who actively engage in particular community. Punk or underground community becomes regular costumers of tattoo studios because this group cannot be detached from tattoo as part of their sense of belonging. In Indonesian context, most of them are culturally Muslim with different fashion, life style, and expression. One of punk communities namely Punk Muslim endeavors to integrate both punk culture which identically tattooed person and anti-tattoo of Islam (Sunni). Although the community has claimed as Muslim, some people said that they are truly non-Muslim while others considered them as Muslim.

The phenomenon of Punk Muslim community as Muslims with tattoos has attracted my attention to look at how their tattoo as part of punk identity faces Islamic tenets as well as Muslim society responses in Indonesia. Current research on tattoo as part of body modification in Asian society provided evidences that it remains less acceptable among individuals in the society. Taking predominantly Muslim country of Malaysia as the research sample, Lim described some exploratory insights of society's perception toward people with tattoos. By selecting different cultural background of individuals (Malays, Chinese, and Indians), Lim found that society of Malaysia tent to look tattoing and body piercing as a representation of dark, s form of arts, spirituality, and self-expression. ${ }^{3}$

Some previous studies on tattoos and piercings discussed stereotypes, judgments, criminals, rebellious, deviants, and pathological

${ }^{2}$ Benjamin Hegarty attempted to trace the locations at which the tattooed body and images of it are produced and circulated. Benjamin Hegarty, "The Body and Global Indigeneity: Tattoos, Ethnicity and Small Media in Indonesia”, RIMA: Review of Indonesian and Malaysian Affairs, vol. 47, no. 2 (2013), pp. 1-23.

${ }^{3}$ Weng Marc Lim et al., "Contemporary Perceptions of Body Modifications and Its Acceptability in the Asian Society: A Case of Tattoos and Body Piercings", ASS Asian Social Science, vol. 9, no. 10 (2013), p. 40. 
toward person or group with tattoos in the Western context. DeMello explored the view of Western society that most people have continued to associate tattooed person with rebellious and criminals. ${ }^{4}$ Atkinson discussed in his research that tattoo enthusiasts relate to the self-identity, deviance, bodily control, rebellion and group membership, albeit they do not agree on what tattooing is all about. ${ }^{5}$ He further concluded that his research participants used their tattoos as a form of emotional expression. It is way for tattoo enthusiasts to manage and control their emotionality, especially useful to express the feelings of grief and loss. Then the terms of being different, self-identity, and deviance were highly recognized as strong motivations for tattooing. ${ }^{6}$

Where connections with deviant behaviors or deviances are examined in the Western, researches among tattooed individuals have resulted various findings. In criticizing the term of deviance in the tattoo discussion, Kosut explored the discourse of deviance itself by looking at the historical development of tattoo. He believed that the discourse of deviance on tattoo is relative, not merely embedded in negative meaning and influenced by the shift of cultural boundaries over time. ${ }^{7}$ After conducting research to the Christian students' perspective toward tattoo in the US, Firmin argued that Bible did not forbid tattooing practices, their friends generally were encouraging of the participants' decisions to tattoo, and students chosen tattoo as spiritual expression rather than rebellion or deviance in the choice to tattoo. ${ }^{8}$ In line with Firmin,

${ }^{4}$ Margo Demello, "The Convict Body: Tattooing Among Male American Prisoners", Anthropology Today, vol. 9, no. 6 (1993), pp. 10-3.

5 Michael Atkinson, Tattooed:Tthe Sociogenesis of a Body Art. (Toronto: University of Toronto Press, 2003).

6 Michael Atkinson, "Tattooing and Civilizing Processes: Body Modification as Self-control*", Canadian Review of Sociology, vol. 41, no. 2 (2004), pp. 125-46..

7 Mary Kosut, "Mad Artists and Tattooed Perverts: Deviant Discourse and the Social Construction of Cultural Categories", Deviant Behavior, vol. 27, no. 1 (2006), pp. 73-95.

${ }^{8}$ M. W. Firmin, Tse, L. M., Foster, J., \& Angelini, T., "Christian student perceptions of body tattoos: a qualitative analysis," in Journal of Psychology and Christianity, 273.1 (2008), pp. 195-204. M... Firmin et al., "Christian Student Perceptions of Body Tattoos: A Qualitative Analysis", Journal of psychology and Christianity., vol. 27, no. 3 (2008), pp. 195-204. 
Camacho gave evidences that the practice of tattooing as a marker for deviance does not appear in the research on arrestees in Florida, US. ${ }^{9}$ Similar findings also appear in Nina Cesare survey that tattooing itself is not a characteristic of the deviant activities. Cesare argued that tattooed people tend to marginalize themselves and not integrally deviant. ${ }^{10}$

As alluded above explanations which emphasize rejection on tattoo as deviance, other researches proposed evidences on the image of individuals with tattoos as marginal and deviance in some public milieus. Adams, for example, criticized Kosut who argued that tattooed individuals commonly associated with criminals and psycopaths because they situated at new representation and discourses. ${ }^{11}$ Following Adam, Kosut's thought justified that even though tattoing is being investigated as an arts or personal identity representation, it still has an aura of marginality and deviance. ${ }^{12}$

Adam's work is inherently comparable to Tabassum's observation on the stigma among tattooed person in their career. The results propose stigmas associated with tattoos remain embedded in the context of culture, especially within career. By interviewing diverse range of occupations including student, small business owner, and employment in the fields of business, pharmacy, and information technology, the observation verified that social stigmas related to the tattooed individuals were conscious by the participants. ${ }^{13}$ Those results were also inherent with some previous findings ${ }^{14}$ that witnessed stigmatized definitions of people with tattoos

${ }^{9}$ Jocelyn Camacho, "The Tattoo: A Mark of Subversion, Deviance, or Mainstream Self-Expression?”, Master's Thesis (Florida: University of South Florida, 2014).

10 Nina Lyn Cesare, "Wearing Your Life as a Sleeve: Examining Tattooing as a Form of Postmodern Identity Expression”, BA Thesis (Ohio: Ohio University, 2011).

11 Kosut, "Mad Artists and Tattooed Perverts", p. 91.

12 Josh Adams, "Marked Difference: Tattooing and its Association with Deviance in the United States", Deviant Behavior, vol. 30, no. 3 (2009), p. 288.

13 Naomi Joy Tabassum, "Tattoo Subculture: Creating a personal identity in the context of social stigma", M.A. Thesis (North Dakota: North Dakota State University, 2013).

14 Benjamin A. Martin and Chris S. Dula, "More than Skin Deep: Perceptions of, and Stigma against, Tattoos", College Student Journal, vol. 44, no. 1 (2010), pp. 1-10; Silke Wohlrab et al., "Differences in Personality Attributions Toward Tattooed and 
in modern American culture, such as drug user and deviant.

When studies on people with tattoos as deviance remain academically debate in the Western, Liem's work on multiethnic perception in Malaysia toward tattooed individuals showed that a large majority of participants associated them with gangsters and criminals. ${ }^{15}$ In the similar Muslim predominantly country of Asia, Indonesian people tend to view individuals with tattoos as deviant. Tattoos become negative symbols stepping away from the societal norms. Besides, the symbol of the tattoo leads to signify an "otherness". Good people will follow society's norm such as faultlessly dressed, piety person (in religious norms), and significantly not tattooing and piercings. ${ }^{16}$

These current researches on societal perceptions of tattoo in Muslim predominantly country (Malaysia and Indonesia) in Southeast Asia, however, are often confined to describe multiethnic society. To be specific, while the body of literature enlarge to understand societal perceptions toward tattooing in American and European culture and multiethnic of Southeast Asian country, little data exist regarding the Muslim society perceptions toward tattooed individuals or even perception within Muslim society to Muslim with tattoos.

This study attempts to provide some insights on the modernday perceptions of tattoo within Muslim society and its debate from a Southeast Asian point of view. To deal with that, this research focuses on Muslim community of Punk Muslim with permanent tattoo as part of their cultural identity. Based upon the literature, Muslims with tattoos are likely to face stigmatization of deviance on some levels. Besides, tattoos have been associated with identity construction and freedom expression. It leads to two central questions; 1) how have Punk Muslim assigned meaning tattoos to their identity? and 2) how have they responded to the perceptions of society?

Nontattooed Virtual Human Characters", Journal of Individual Differences, vol. 30, no. 1 (2009), pp. 1-5; Derek John Roberts, “Secret Ink: Tattoo's Place in Contemporary American Culture", The Journal of American Culture, vol. 35, no. 2 (2012), pp. 153-65.

15 Lim et al., "Contemporary Perceptions of Body Modifications and Its Acceptability in the Asian Society", p. 39.

16 Hatib Abdul Kadir Olong, Tato (Yogyakarta: LKiS, 2006), p. 35. 


\section{B. Methods}

In order to provide some empirical data relate to above questions, this study used three methods of data collection: individual interviews, a focus group discussion, and interactive social media communication. In the interview and discussion method, I began to reread my ethnographic notes when conducting research on Punk Muslim movement in Indonesia. ${ }^{17}$ Some updated information that show both Punk Muslim and society expressions and opinions toward Muslims tattoos was taken via interactive social media communication. There were debate between people who gave support to tattooed Punk Muslim and who insisted tattoo for Muslims. The debate happened in some social media such as facebook and youtube, especially in the space of comments provided by youtube.

When conducting interview, "snowballing" technique was helpful to gain significant information either from individual or group. Face to face interviews provide valuable in-depth data because informants usually enjoy to talk privately and express their personal knowledge and experiences. It helped me to extract relevant content and research focus. In the individual interviews, I found some explanation on special terms that usually did not appear in group discussion and participation in some activities. Open-ended responses also appeared in this way compare to the group situation because some people tend to be silence in a group forum.

I employed focus group discussion with both Punk Muslim community and society around them. Along with my participation in some Punk Muslim activities, I gathered them in some focused forums and sometimes in a dinner together. Besides, after some religious activities (prayer together of salat jamaah) in the mosque near Punk Muslim's boarding house, I discussed with some Punk Muslim's neighbors relate to their perceptions toward Punk Muslim attitudes and activities. Group interviews allow me to observe the way in which individuals justify and defend their personal opinions and positions. Debating other opinions frequently occurred in this way.

Social media communication formed the additional method of

${ }^{17}$ Mohammad Rokib, Punk Muslim: The Emergence of New Muslim Youth Movement in Indonesia (Bangkok: Asian Resource Foundation, 2014). 
data collection in this research. I used this medium in order to gain further information on Punk Muslim's and other people's opinion toward the use of tattoos for Muslims. The two interactives media such as facebook and youtube became significant to collect data on polemic of tattoo particularly when responding the use of tattoo for Punk Muslim members. In this virtual forum, I easily identified participants through their personal page of facebook and youtube to trace their representative. Punk Muslim's Facebook fan page has 24.579 likers who usually comment on updated status as status of tattooing in Islam. There were almost hundred comments on the topic of Muslim with tattoo. Similar comments also happened in an uploaded Punk Muslim's video on youtube. These comments on social media enriched my data on the debate on Muslims with tattoos.

\section{Punk Muslim Community}

Punk Muslim is one of punk groups name attempting to amalgamate punk culture and Islamic teaching. In general, punk culture has unique lifestyles that actively resist mainstream society and often oppose to traditional/normative norms and values. Like other punk groups, Punk Muslim characters attach to hard and fast music genre as well as its rebellion toward political/religious environment. Expression of freedom culture through hard rock music, dark t-shirt with an offensive slogan, unique or multicolored hair styles, tattoos, and anti-governmental rules become their personality. As a subculture movement, the community is often characterized by a do-it-yourself ethic and is disengaged from mainstream society. These punk lifestyles come together with Islam in real life which leads them to believe God of Allah, do everyday prayers, and create Islamic lyrics to their underground music.

The name of Punk Muslim was firstly mentioned by people around their boarding house in 2002. The name refers to the founder of "Warung Udix Band" group led by Muhammad Budi Khoironi or Buche, a punker and street musician in Pulogadung Jakarta. All of Warung Udix Band group actively engage in Islamic rituals such as prayer together and distributing zakat. Rather than Warung Udix Band, people called them Punk Muslim. It continues to 2007 when Buche met with an accident and passed away at a hospital in Jakarta. Before his death, Budi instructed 
his spiritual advisor, Zaki, to continue activities regarding punk ethics and Islamic practices.

Currently, this group has twenty permanent members and some leaders in Jakarta. Darma, Asep, Mongxi, and Luthfi are the next activator of Punk Muslim. Encountering with other communities encourage this group to broaden networks throughout Java Island and so on. As result, the group has some networks/branches in Surabaya, Semarang, Brebes, Indramayu, Batam, Cimahi, Pontianak, Aceh and Malaysia. There were no data available about their members outside Jakarta.

Rather than expressing punk culture, Islamic practices are predominant activities within this group. Based on my participant observation, there are three main activities showing the Islamic expressions such as prayer together, Punk kajian (study group on learning Islam using both Islamic novel and non-fiction $)^{18}$, and creating underground music with the Islamic lyrics. Even though they have other routine activities including mengamen or singing on the streets, screen-printing business, and washing motorcycle business, the nuance of Islam occurred within those activities. Islamic lyrics, for example, become their choice when singing on the streets. When getting income from the business activities, they collect few of it to fund activity of study group on learning Islam. The group also annually invites their networks in Java Island to meet and perform nasyid underground songs (underground music with Islamic lyrics).

\section{Understanding Tattoos in Indonesian Islam}

It was evident that the discussion with Punk Muslim's neighbors had predictable ideas as to what the Islamic sect of Sunni explains about tattooing. In the discussion, participants generally argue that tattoo can prevent validity of prayer and such religious practices. One of participants, Tirmidzi, emphasize the dangers of having permanent tattoo as it can abolish ritual ablution for Muslims. He, further, said:

${ }^{18}$ Dealing with learning Islamic tenets, they collect some references such as iqra book (reading Qur'an for beginner), prayer guidance book, and popular Islamic novels. Most of their references are donation from other Islamic groups as well as individuals. Reading popular Islamic novels is a side activity to engage in the dynamic of contemporary Indonesian Islam. See Mohammad Rokib, "Reading Popular Islamic Literature: Continuity And Change In Indonesian Literature", Heritage of Nusantara: International Journal of Religious Literature and Heritage, vol. 4, no. 2 (2016), pp. 183-94. 
Islam kan sudah jelas-jelas melarang sesuatu yang kotor seperti tato. Kalau badan kita kotor, otak kita juga kotor. Lihat saja itu gaya Punk. Muslim. Mereka itu orang kotor karena tidak menghapus tato di tubunya. Itu dilarang dalam Islam punya tato k.arena dapat membatalk.an wudhu untuk salat. Jadi orang Islam itu ya harus bersih dan suci. Mereka itu nggak bisa menyebut diri Muslim sebelum menghapus tatonya. ${ }^{19}$

Islam clearly forbids a dirty things such as tattoos. If our body is dirty, our mind can be dirty too. Look at the Punk Muslim's styles. They are dirty people because didn't clean their tattoos in the body. It is forbidden in Islam to have permanent tattoo because it can abolish their wudhu (ritual ablution) before prayers. Being Muslim must be clean and pure. They cannot claim their self as Muslim before erasing their tattoos.]

Similarly, Tarmidzi's colleague, Hasan, stated that their prayer is nothing because they did not comply with legitimate requirement of wudhu. The statements of Punk Muslim's neighbors reflected their rejection to not only the use of tattoo for Punk Muslim but also insisted tattooed person as Muslim. They portrayed themselves as individuals with Islamic integrity by practicing $w u d h u$ without having dirty things as tattoos. Both of them expressed confidence that Islam provide regulations against tattoo.

Responding the case of Punk Muslim members with permanent tattoos, other participant articulates tattoo as dirty things due to accident. Because permanent tattoo is difficult to erase and can cause deep injury, it should be considered by Islam. Dian believes that tattoo is a dirty things and cause of ritual ablution but removing permanent tattoo from skin can cause injury or torture. As Punk Muslim's neighbor, individuals like Dian tries to reflect the group members' attitudes and the spirit of Holy Quran. However, Ali return to the prohibition of tattoo and attempts to search it in the Holy Qur'an. He illustrates:

Saya tidak tabu banyak tentang aturan-aturam tato di dalam Qur'an. Seingatku dalam Qur'an ya tidak ada penjelasan jelas tentang tato. Jika tidak salah, pendapat tentang tato itu berasal dari sebuah hadis yang dijelaskan lagi oleh ulama. Sebagai orang Islam, kita ya harus percaya Nabi Mubammad sebagai sumber kedua kita. Tato jarang sekali dibicarakan dalam buku pegangan kita, tapi kan tetap mudah disamakan dengan sesuatu yang kotor, iya kan. Jika kita kotor, kan harus membersibkan diri agar bersih. Tuhan itu cinta yang bersih dan itu kan bagian dari

19 Interview with Tarmidzi, 20 July 2013. 
iman, annadhafat min al-imaan. Saya dengar bahwa profesor Quraish Shihab juga melarang tato bagi orang Islam. ${ }^{20}$

I don't know very much about tattoo regulation in the Quran. In my knowledge on Quran, there is no exact explanation about tattoo. If I don't mistaken, it comes from hadith (Prophet Muhammad's words) that is explained by other Muslim scholars. As Muslim, we have to believe words of Prophet Muhammad as the second source of Muslim guidance. Tattoo is rarely discussed in our reference books, but we can easily analogize it to the dirt. If we are dirty, we have to clean up the dirt so clean. Our God loves cleanliness and it is part of faith, annadhafat min al-imaan. I heard that Professor Quraish Shihab also prohibits tattoo for Muslim.

As alluded to above by Ali, tattoo is categorized as dirty, oppose to cleanliness or purity. He refers to his memory on Quran and Sunnah as well as Muslim scholars' opinion, Quraish Shihab. Likewise, the most contemporary prominent Indonesian Muslim scholars, Muhammad Quraish Shihab, wrote in his book that there are huge amounts of hadith which forbid tattoo for Muslim. He emphasizes that tattoo can block the entry of water to Muslim skin when practicing wudhu. In a debriefing book, Shihab answered some questions regarding tattooed Muslim, Islamic jurisprudence on tattoo, the case of tattoo in the prophet Muhammad period, and permanent tattoo for Muslims. He commented:

Tato sudah dikenal sejak zaman Rasul SAW. ...tato yang menghalagi tersentubnya air wudhu atau air mandi junub apapun gambar atau tulisan pada tato itu sangatlah terlarang. ...Suatu ketikea ada yang mengulurkan sesuatu kepada Nabi SAW di belakang tabir, beliau bertanya apakah ini tangan wanita atau pria. Istri beliau Aisyah $\mathrm{Ra}$ menjawab bahwa itu tangan wanita. Ketika itulah beliau bersabda: Tidakkah baiknya dia memakai pacar untuk memperindah kukunya? ...Tato bendaknya dihapus/dibilangkan, tetapi jika upaya menghilangkannya akan dapat mengakibatk an cacat, maka upaya tersebut tidak perlu dilakukan, cukup beristighfar dan memohon ampun Ilahi sambil menyesali perbuatan itu dan bertekad tidak. mengulanginya. ${ }^{21}$

Tattoo has been known since the time of the prophet Muhammad. ..._when there is something blocking the water gets into the skin for

\footnotetext{
20 Interview with Ali, 19 July 2013.

21 M. Quraish Shihab, Mistik, Seks, dan Ibadah (Bandung: Republika, 2004), pp.
} 64-6. 
purification (wudhu), the images or tattoos are forbidden. ... One day there is someone who reached out to Muhammad from behind the curtain, he asked whether the man or woman's hand. Muhammad's wife, Aisha, replied that it was a woman's hand. Muhammad said: why you do not use henna to beautify your hands?..._tattoos should be removed, but if an attempt to remove it may cause defects, then the effort was not necessary. She/He needs to seek forgiveness in Allah and promised not to repeat.

Notwithstanding that Ali mentioned Shihab's notion as his inspiration, Shihab's points slightly different with Ali statements. In the end of above quotation, Shihab precisely describes an exception to Muslim with permanent tattoos. It implies the possibility for Muslim with tattoos to do worships or prayers. In a casual interview with Punk Muslim member, he hopes that Islam will accept his belief although permanent tattoo is still painted in his skin. Before joining Punk Muslim, he did not know that it is forbidden in Islam because it looks like art of paintings. He illustrated this as he spokes metaphorically concerning permanent tattoo in Islam: "You can see this good picture. It is just a picture. It is not a Satan or devil. It is good thing. I feel difficult to remove it. It is dangerous to erase. I believe Islam loves something beautiful and this picture (tattoo) is beautiful." 22

Another Punk Muslim member who did not have tattoo believe that permanent tattoo is portrayed as wound in the skin when an accident occurred in the past. This member concluded that wound cannot absorb water to skin through the pores and it is similar to permanent tattoos. The member remarked an opinion:

Aku nggak pakai tato tapi bagiku sib tato seperti yang dipakai temanku itu sama saja dengan luka kulityang sudah lama seperti babis kecelakaan. Kita tabu itu nggak. mungkin dihapus apalagi bagi orang awam dan miskin seperti kami. Kita butuh uang banyak untuk. menghilangkan tato itu. Kalau masalabny a adalab terbalangnya air masuk. ke kulit untuk. wudhu, kulit yang terluka dan luka bekas juga sama. Bagiku sib, Islamku nggak, sempit kok untu ngatasi masalah itu. ${ }^{23}$

I am not tattooed person but I think permanent tattoo, as my friends have, similar to the wound that is painted in the past, especially when accident occurred. We know that it is impossible for lay people and poor

22 Interview with Imam Maulana, 27 July 2013

23 Interview with Kotak, 18 July 2013 
people like us to remove it. We need much money to erase permanent tattoo. If the problem is because the hindered water to enter to the skin for purification, injured skin and wound have identical case. My Islam is not narrow to think about that, in my opinion.

In line with above remarks, administrator of Punk Muslim Facebook page responded to some comments on the questioned legitimation of wudhu as prayer requirements. It was said that Punk Muslim submits their matters as tattooed person to the God. Some comments justify the useless of wudhu for tattooed individuals. However, Punk Muslim believe that God will be understand their intention for repentance. Administrator elaborated:

Ya, betul. Tato itu berbubungan dengan syarat sah wudhu...tentang masalah apakah itu mensabkan wudhu dan salat kita diterima tuhan atau tidak, hanya tuhan yang tabu. Allah itu maha penerima taubat. Membuat tato di badan itu menyiksa diri sendiri, tapi menghapusnya juga akan melukai diri sendiri... ada kok beberapa ulama yang punya pendapat wudhu orang bertato masih sah. ${ }^{24}$

Yes true. Tattoo is relate to a legitimate requirement of wudhu. ... About the case whether it is legitimate ablution and our prayer acceptable to God or not, only God knows. Allah is the recipient of repentance. Painting tattoo in the body is oppressing ourselves, but removing tattoos will be hurt ourselves too. ...there are few Muslim scholars who argued the wudhu of tattooed person is still legitimate.

There were no mentioned Muslim scholars who are referred by Punk Muslim within their statements. However, it can be trace to the availability of Islamic sects in Indonesia. Firstly, Indonesian Muslims can refer to Indonesia Council of Ulama (MUI) if shaping problems deal with Islamic jurisprudence. Secondly, there are two major Muslim organizations in Indonesia namely Muhammadiyah (founded in 1912) and Nahdlatul Ulama (founded in 1926). The polemic of tattooed Muslim in Indonesia is usually attached in the fatwa of both organizations. The organizations have influenced Indonesian Muslim perspectives and attitudes toward certain issues include tattooing. Another option is following a prominent Muslim scholar such as M. Quraish Shihab.

While Quraish Shihab agrees to forbid tattoo but still consider

24 Punk Muslim Facebook page, accessed 5 January 2014. 
tattooed person permanently not to remove it, Indonesian Council of Ulama (MUI) tend to forbid it. In a fatwa number 26 (2013) on permitted cosmetic products, MUI quoted prophet Muhammad's words that women who have tattoos, shorten hair, and change God's creation is cursed by God. Similarly, the official website of NU released that the forum of Islamic boarding schools throughout Java and Madura forbids tattoo in the eyebrows. This forum based on the reason that either in the Qur'an, hadith, or Islamic jurisprudence, none of these sources could be used as justification for practices that ultimately is changing the creation of God. ${ }^{25}$

Unlike MUI and NU, Muhammadiyah team of tarjih (Islamic legal affairs) released a decision on the status of tattoo in Islam. Based on Quranic verse (al-Kahfi: 7), Muhammadiyah believes that tattoo is a kind of jewelry. In the website of www.fatwatarjih.com, this largest Islamic organization in Indonesian concluded that tattoo basically is permissible (mubab) because it includes jewelry. But if the consequences of making tattoo are negative, or it can reduce belief, morality and so on, so the law can be change into makrub or haram (forbidden).

\section{E. Punk Muslim with Tattoos}

There are three to five members of Punk Muslim who have permanent tattoos in their body. All of them painted the body when became street punkers before joining Punk Muslim. They did not know whether it is permanent or not when they were painted by other punkers. One of members, Asep, has many tattoos in his hand and body which sometimes makes him not confident to sing and perform music in the performance. In Ramadhan month in 2013, for example, he covered his tattooed hand by using casual long hair jacket. He admitted that as punker who embraces Islam, has Islamic symbols in the community's name, and lives in Muslim society, tattoo creates negative image for him and other members.

Despite negative images is always directed at Punk Muslim with tattoos, there are particular reasons why they painted the body. The main reason is because most of their friends have tattoos as an identity of punkers. According to Anang, for instance, punk identity is all

25 See http://www.nu.or.id/post/read/35445/santri-se-jawa-maduraharamkan-tato-alis-mata, accessed on 7 January 2014. 
about tattoo, clothing, and life styles. "No punkers without tattoos", he emphasized. Currently, some members of Punk Muslim have no tattoo because it has been removed when joining the community. To same extend, permanent tattoo is exception to be erased considering the effects after removing: physical defect. Another reason to let tattooed body is the expensive fee to remove it in a save medical methods. This case leads to the consequences on the meaning of tattoos to their own sight.

Tattoos bring them to understand social norms in Muslim society as in Indonesia. They are gradually able to realize awareness toward personal meaning of tattoos. In this sense, tattoos can strengthen bond of friendship among punkers. If punker meet with other pukers who have tattoos, they unconsciously feel in similar status such as naughty, criminal, and non-normal person. A Punk Muslim member told in buoyant spirit that their community is always reputed as an "other" and weird person in society because of tattoo and disheveled appearances. They feel have the same fate as naughty, criminal, and non-normal boy. Thus they can easily say hello each other when meet tattooed person. ${ }^{26} \mathrm{It}$ indicates insider perspective on the status of tattooed punkers in society as a different group.

Punkers' appearance primarily designed social identity rather than personal identity. The way of dressing and tattooing not become entirely dissociated. Dress and tattoo construct a social identity and remain a signaling device of class position, gender, and group. Then the appearance of tattooed individual become a central element in the reflexive project of the self. Identity of tattooed punkers cannot be detached from the perception of mainstream society and individual reflection. If, for example, tattooed boy expresses normal attitudes within society, not to make resistance or uniqueness, perhaps tattooing will be understood as a normal. A tattooed Muslim artist in Indonesia, Tora Sudiro, has also tattoos in his body as an art. He is a Muslim who possibly practices five times prayers. Negative images are not addressed to him and he is still accepted as a popular Muslim artist by society. This case is a bit different compare to member of Punk Muslim who is justified by society as not Muslim, even as an iblis (the head of the devils).

However, Punk Muslim members believe that negative image is

${ }^{26}$ Interview with Kotak, 18 July 2013 
a challenge to survive and gives a pride. Asep is an example of proud tattooed punker. In an interview taken by an Indonesian television channel, Asep proudly showed his tattooed hand when conducts a live interview. Regarding his tattoo, he confidently said: "I do what I want. People may be judged this (tattooing) in negative terms. But this is me, this is part my identity and my personal history that I am a boy like this", ${ }^{27}$ To deal with negative image, Asep and other Punk Muslim members do Islamic practices to differentiate with other punk groups. He also do not reject negative terms but attempt express what they want and believe as punkers and Muslim.

In some extend, Punk Muslim members acknowledges that there are certain spaces in which they felt proud to show off their tattoo. Music performance in a punk community meeting become important to show tattoo. Streets are also significant place to show the tattoos in public spaces.

...seperti anak punk lainnya yang punya tato sebagai simbol punk. Kita jelas menunjuk.kan tato sebagai bagian darinya. Aku sendiri dan temanku bergaul dengan anak punk, rocker, dan pecinta aliran musik rock. dan masing-masing punya gambar tato yang beda. Itu bal yang terpenting. Aku suka kumpul-kumpul seperti ini karena aku aslinya anak punk tapi aku ingin punya masa depan baik. sehingga percaya dan melaksanakan ajaran Islam. Aku pingin merasakan surga bila mati kelak. ...untuk mencari perhatian. Tato bisa menaik.kan status sebagai orang kriminal di jalanan. Aku nggak suka kayak gini tapi ini ada bubungannya dengan pendapatan ketika mengamen di jalanan. ${ }^{28}$

...like other punkers who have tattoo as a symbol of punk. We definitely show our tattoo as part of them. My friends and I mingle with punkers, rockers and other hard rock music likers and each of us have different symbol of tattoo. That's one of big things. I love to this kind of meeting because my background is originally punkers but I want a good future so that I believe and practice Islamic teaching. I want to taste heaven when died. ...to gain attention. Tattoo can enhance our status as criminal person in the streets. I don't like this but this relate to my income when performing a music in the streets.

27 Transcripted from Esther Mulyanie (producer), "Hidup di Jalanan Tapi Religius Beginilah Punk Muslim”, Liputan Siang SCTV, accessed on 25 December 2014.

${ }^{28}$ Interview with Imam Maulana, 17 July 2013 
In contrast to show off tattoo in public spaces that it can be understood by society, Punk Muslim shows their tattoo in the religious expression too. Doing such religious practices as prayers and reading Quran, they do not cover the tattoo either in private or public spaces. When doing payer together in the dormitory, most tattooed members did not cover their tattooed hands. Some people near the dormitory said that it was impolite and did not respect the God because they meet God when they were praying or reciting Qur'an.

Tattoo exposure may be a barrier to Islamic worship that every tattooed person could be disturbed by disapproval society. All members reported unexpected experiences from society in the region. Kotak tried to ignore various reproaches but felt difficult. He regretfully spoke about his annoying to hear neighbor that pout his activities. Sometimes they accuse Punk Muslim activities as feign and not truly practicing Islam. It makes him upset. ${ }^{29}$ Indeed, society's attitudes toward Punk Muslim have influenced their freedom of expression, nonetheless this group endeavor to disregard them.

\section{F. Responses on Tattooing}

There are some responses toward tattooed individuals in Punk Muslim. These responses addressed directly to tattooed members and the group in general either in real or virtual world. In the real world, responses come from different social classes in society. As noted before, negative image on tattooed Punk Muslim was addressed by the neighbors who actively engaged in religious activities in the mosque near boarding house. In my observation, most of them originated from upper class in terms of economy by looking at their dresses and houses. Tirmidzi who assumed tattoos in the body as dangerous and dirty things did emphasize to erase it. He believes that it is forbidden in Islam because it can abolish the ritual ablution of wudhu. Even, he judged that Punk Muslim with tattoo is not truly Muslim before removing the tattoo.

Other neighbors such as Hasan and Ali returned to the Holy Quran to explain that tattoo is definitely prohibited in Islam. By quoting Islamic teaching on purity, Ali convinced that "Allah is beautiful and love

29 Interview with Kotak, 18 July 2013 
beauty" as well as "cleanliness is a part of belief". ${ }^{30}$ As consequences, they categorized Punk Muslim members with tattoos as non-Muslim and their efforts are fruitless.

Contrast to the mentioned neighbors who actively engaged in mosque activities, some lay people near boarding house appreciated Punk Muslim activities. They expected that the community can find the appropriate ways to express Islam in an exceptional situation. One of the neighbors, Wawan, believes:

Nggak masalah mereka apa. Anak nakal keek, kriminal kek, pencopet keek, perampok, kek, atau peminum kek, apapun itu. Kita tetap menghormati usahanya jadi lebih baik. Saya ini orang Islam yang goblok, sebab nggak tabu banyak tentang Islam terutama Qur'an dan Hadisth. Tapi sebagai manusia, saya tetap percaya Tuban membolehkan salat meskipun tatonya masih ada di badan. ${ }^{31}$

No matters what their backgrounds. Naughty boys, criminal person, pickpockets, robbers, or drinkers, whatever. We must respect to their efforts to be better. I am a stupid Muslim because I don't know much about Islam especially Quran and Hadith. But as a human being, I believe our God will allow them to do prayer even though their tattoo is still attached in the body."

From another similar perspective, there are Muslim student association (HMI) from Islamic State University (UIN) Syarif Hidayatullah Jakarta who invited Punk Muslim to perform their music skills and share the experiences on becoming punker and Muslim. In a casual interview when I met those students in boarding house, they stated that Punk Muslim life style is not merely normative practices of Islam but innovative Islam. "Islam is not a single form but it can be expressed in various ways. Different opinion in Islam is real but we can conclude that Islam will accept their (Punk Muslim) worships although there is tattoo in the body", a coordinator of students said. Besides, other students remarked that differences in Islam are always happen by telling the history of Islamic sects. He argued that there are many Muslim scholars who allowed tattooed individual to do prayers without any particular requirements. Interestingly, he told that tattooing tradition existed in the period of Prophet Muhammad but no special regulation

${ }^{30}$ Interview with Ali, 19 July 2013.

31 Interview with Wawan, 20 July 2013. 
on that tattoo when doing prayers.

Both neighbors and students responses tend to defend Punk Muslim's practices as unique practices without rough speeches. The insulting responses occurred in virtual world namely social media of internet. Considering the use of social media in Indonesia, this work focuses on two prominent interactive social media of facebook and youtube. By selecting updated status on tattoo in both facebook and youtube, several responses occurred to attack, insult, stigmatize and defend or appreciate Punk Muslim action.

In May 2012, Punk Muslim facebook page posted a comment on the issue of tattoo relates to Islamic teaching. Almost hundred comments suddenly addressed to the Punk Muslim updated status. Satirical comments came insistently while few of them stigmatize the community. The most active commentator of Jhon Sam (from Jakarta), for example, commented that Punk Muslim members should remove their tattoos in order to gain perfect prayers. Part of his satirical comments orderly stated that:

Toh kalo syarat dalam sholat tidak dilakukan. Toh sholat nya ngx sah kali!! Makanya sering denger ceramaaaaabhbh di mesjid dan di TV...

INGEETT DALAM AGAMA ISLAM TATTO ITU HARAAAMM HUKUM NYA.? karena allab melahirkan kita tanpa tinta di tubub kita? Dan allah juga ingin kita kembalipada nya tanpa tinta juggaaa..!! saya mau liat adakah orang yang di page ini bilang TATTO itu hallal.? Dan terangkan hadit mana yang menyatakan tatto itu hallal bukum nya dan sah untuk. melakukan sholaat..?

Dan buat zionis punk.!! Kalo anda merasa anda punya salab sama tuhan.!! Seharus nya jika anda berbuat anda berani tanggung resiko nya! ${ }^{32}$

If the legitimate requirements of prayers is not done, it is absolutely illegitimate. Therefore you have to often hear Islamic teaching in mosques and television...

REMEMBER! TATTO IS HARAM IN ISLAM (emphasis as written in original text). Allah creates human beings without ink in our body and Allah wants we return without ink too. Is there any statement that tattoo is halal (permitted). Which hadith that describes about that...

${ }^{32}$ Cited from Punk Muslim facebook fan page on 2-3 June 2012. Accessed on 6 January 2014. 
for Zionist punk...if you feel that you have mistakes to God, you must have the courage to bear the risk. Remove your tattoo and don't be afraid to feel pain because it is the consequences.

Punk Muslim facebook page administrator responded that legitimate requirements of prayers are determined by God. They believe that God will receive their repentances. Whether their tattoos are prohibited or permitted, this community rely on prominent Muslim scholars. A problem to remove permanent tattoos is about the financial and potential physical defect. In line with this statement, Syah Sabar (from Yogyakarta) commented that the urgent thing for tattooed Punk Muslim is repentance. "Tattoo is a khilafiyah (different opinion one another). The problem should not be extended. We don't know when we will die." 33 Syah Sabar seems support Punk Muslim but he still considers the statement of John Sam in the same time.

Other facebook friends of Punk Muslim totally support Punk Muslim. Hilman Taufik said that the community must go on. Tian Bastian, Amink Mogers and others commented that most of perpetrators are people without tattoo, killings are often done by non-tattooed person, and Prophet Muhammad did not differentiate his ummah to do kindness. In the facebook forum, stigmatizing tattooed members of Punk Muslim are few compare to support toward them. However, most comments criticize the possibility integration between punk culture and Islam.

While facebook commentators tended to support and criticize, most comments in youtube reproach the existence of tattooed members of punk Muslim. Hafiz Saarani, for example, claimed Punk Muslim as bad as Taqwacore and this group is Syiah. Then he concluded Syiah is haram and Punk Muslim is also haram. Similarly, Aizat Norisham noticed that Punk Muslim has disfigure Islam through bad attitudes as tattooing and screaming. ${ }^{34}$

Some commentators in youtube categorize Punk Muslim as worst symbols in Islam. Unfortunately, they did not give reason on its

33 Cited from Punk Muslim facebook fan page on 2-3 June 2012. Accessed on 6 January 2014.

34 The polemic of tattoos among Punk Muslim members occured in youtube comment which is uploaded by punkmuslim subscriber entitle "Muhammad SAW Idol". See https:/ / www.youtube.com/watch?v=loYsWYA1vUQ accessed on 7 January 2014. 
comments. Satan, devil, and dajjal are symbols attached to the Punk Muslim community. Other commentators mentioned tattoo as a symbol of devil, while another commentator judge their hard rock music as dajjal symbol. One of discussants, Kasina Ruruy, clarified and questioned the explanation on music as something forbidden or haram in Islam. ${ }^{35}$ Unfortunately no one answered that question.

\section{G. Concluding Remarks}

As noted, Punk Muslim members in this study generally believe their decision to embrace punk culture and Islam did not violate Islamic teaching. That is, they looked for Muslim scholars opinion on the possibility of tattooing, especially the existence of permanent tattoo for punk Muslim with tattoo. Under all circumstances, Punk Muslim considers to maintain their cultural identity as punker symbolized by tattoo and Islam signed by worship as well as other religious practices. By looking at various responses on tattooed Punk Muslim, we refer to the Islamic texts used by Muslim scholars and society to describe the case of Muslim with tattoos. Besides, interpreting contextual phenomenon become significant way in this work.

Even though tattoo is a peripheral issue in Indonesian Islam, people often give responses to the case and address question to Muslim scholars. Most of interviewed person near Punk Muslim boarding house stigmatized the community as dirty people based on the tattoos. Their opinion refers to the Islamic text on the cleanliness as part of belief. Then, if a Muslim has Islamic belief, she/he must clean and not dirty. According to them, this reason is applicable to the tattooed Punk Muslim. MUI, NU and Quraish Shihab take place tattoo as forbidden because none of Islamic text could be used as justification for practices that ultimately is changing the creation of God. To be noted, Quraish Shihab provides exception to people who have permanent tattoo before believe in Islam as what Punk Muslim case. Contrast to these opinions, Muhammadiyah argued that there are three types of Islamic perspectives on tattooing namely mubah, makrub and haram. For permanent tattooed Muslim, this organization has similar opinion to Quraish Shihab. Therefore the status

35 See https://www.youtube.com/watch?v=loYsWYA1vUQ accessed on 7 January 2014. 
of Muslim with tattoo in Indonesia is debatable depend on the specific case existed.

The consequences of those debated status, Punk Muslim community negotiates their identity as punkers with Islam. The community interprets tattoo as symbol of punk identity, strengthening friendship within punkers, and elements that make them confident in certain space and, otherwise, not confident in some spheres. This is understandable because members defend to have identity of punkers. Negotiation between punk and Islamic culture occurred in the personal and social level. They personally want to remove tattoos to gain comprehensive belief of Islam but it is socially difficult because of identity and friendship consideration.

Indeed, society's responses stigmatize Punk Muslim tattoos but other people support them. As noted above, commentators in punk Muslim facebook page generally support them to express a creativity. Tattoo is not a barrier for the creativity in Indonesian Islam. Contrast to facbook comments, most comments in youtube stigmatize tattoo as worst thing in Islam but there are no reason explained on the stigmatization. 


\section{BIBLIOGRAPHY}

Adams, Josh, "Marked Difference: Tattooing and its Association with Deviance in the United States", Deviant Behavior, vol. 30, no. 3, 2009, pp. 266-92 [http://dx.doi.org/10.1080/01639620802168817].

Atkinson, Michael, Tattooed: the Sociogenesis of a Body Art., Toronto: University of Toronto Press, 2003.

----, "Tattooing and Civilizing Processes: Body Modification as Selfcontrol*", Canadian Review of Sociology, vol. 41, no. 2, 2004, pp. 125-46 [http://dx.doi.org/10.1111/j.1755-618X.2004.tb02173.x].

Camacho, Jocelyn, "The Tattoo: A Mark of Subversion, Deviance, or Mainstream Self-Expression?”, Master's Thesis, Florida: University of South Florida, 2014.

Cesare, Nina Lyn, "Wearing Your Life as a Sleeve: Examining Tattooing as a Form of Postmodern Identity Expression", BA Thesis, Ohio: Ohio University, 2011.

Demello, Margo, "The Convict Body: Tattooing Among Male American Prisoners", Anthropology Today, vol. 9, no. 6, 1993, pp. 10-3 [http:// dx.doi.org/10.2307/2783218].

El Hamamsy, Walid and Mounira Soliman (eds.), Popular Culture in the Middle East and North Africa: A Postcolonial Outlook, New York: Routledge, 2013.

Firmin, M... et al., "Christian Student Perceptions of Body Tattoos: A Qualitative Analysis", Journal of psychology and Christianity., vol. 27, no. 3, 2008, pp. 195-204.

Hegarty, Benjamin, "The Body and Global Indigeneity: Tattoos, Ethnicity and Small Media in Indonesia", RIMA: Review of Indonesian and Malaysian Affairs, vol. 47, no. 2, 2013, pp. 1-23.

Kosut, Mary, "Mad Artists and Tattooed Perverts: Deviant Discourse and the Social Construction of Cultural Categories", Deviant Behavior, vol. 27, no. 1, 2006, pp. 73-95.

Lim, Weng Marc et al., "Contemporary Perceptions of Body Modifications and Its Acceptability in the Asian Society: A Case of Tattoos and Body Piercings", ASS Asian Social Science, vol. 9, no. 10, 2013, p. p37. 
Martin, Benjamin A. and Chris S. Dula, "More than Skin Deep: Perceptions of, and Stigma against, Tattoos", College Student Journal, vol. 44, no. 1, 2010, pp. 200-6.

Mohammad Rokib, Punk Muslim: The Emergence of New Muslim Youth Movement in Indonesia, Bangkok: Asian Resource Foundation, 2014.

Müller, Dominik Michael, Islam, Politics and Youth in Malaysia: The PopIslamist Reinvention of PAS, Abingdon [u.a.: Routledge, 2014.

Nasir, Kamaludeen Mohamed, “Tattooing the Muslim Youth Body", in Globalized Muslim youth in the Asia Pacific: Popular Culture in Singapore and Sydney, Hampshire: Palgrave Macmillan, 2016.

Noor, Farish A., "Popular Religiosity in Indonesia Today: The Next Step after 'Islam Kultural'?", Al-Jami'ab: Journal of Islamic Studies, vol. 53, no. 2, 2015, pp. 283-302 [http://dx.doi.org/10.14421/ ajis.2015.532.283-302].

Olong, Hatib Abdul Kadir, Tato, Yogyakarta: LKiS, 2006.

Roberts, Derek John, "Secret Ink: Tattoo's Place in Contemporary American Culture", The Journal of American Culture, vol. 35, no. 2, 2012, pp. 153-65 [http://dx.doi.org/10.1111/j.1542-734X.2012.00804.x].

Rokib, Mohammad, "Reading Popular Islamic Literature: Continuity And Change In Indonesian Literature", Heritage of Nusantara: International Journal of Religious Literature and Heritage, vol. 4, no. 2, 2016, pp. 183-94.

Shihab, M. Quraish, Mistike, Seks, dan Ibadah, Bandung: Republika, 2004.

Tabassum, Naomi Joy, “Tattoo Subculture: Creating a personal identity in the context of social stigma", M.A. Thesis, North Dakota: North Dakota State University, 2013.

Wohlrab, Silke et al., "Differences in Personality Attributions Toward Tattooed and Nontattooed Virtual Human Characters", Journal of Individual Differences, vol. 30, no. 1, 2009, pp. 1-5 [http://dx.doi. org/10.1027/1614-0001.30.1.1]. 